\title{
Parent-Adolescent Interaction and Outcomes
}

\author{
Prof. Indu Bansal ${ }^{1}$, Sonam Sharma ${ }^{2} *$
}

\section{ABSTRACT}

This study aimed to investigate perception of parent-adolescent interaction, outcomes and also to find out gender differences (girl Vs mother, girls Vs father and boy Vs mother, boy Vs father). Data were collected from 1719 adolescents (692 girls, 1027 boys) studying in 7th (329 boys, 263 girls), 9th (320 boys, 244 girls) and 11th (378 boys, 185 girls) classes of some selected schools of Delhi. Age ranged from 11-17 years. Self constructed questionnaire was used to find out parent-adolescent interaction and outcomes, categorized into 5 dimensions namely; Quality of interaction, Parental support, Kind of Treatment, Punishment and Reward and Criticism/Complaints between adolescents and their parents. Students were asked to mark their responses separately for father and mother, as per instructions provided for each section. Means and standard deviations were calculated. ' $t$ ' test was used to find out significance of difference between means. The result revealed that there are significant differences in parental interaction and outcomes with adolescent of different age groups and sex.

Keywords: Adolescents, Gender Difference, Interaction, Outcome

Transformation from childhood to adolescence is believed to be disturbing, felt not only by adolescents but by their parents as well. Some studies indicate that it is not as stressful as was previously believed (Montemayor, 1983) and suggest that most adolescents enjoy their relationships with parents. Most of adolescents identify parents as significant persons in their lives, and feel more satisfied when parents are present. Though during adolescence there is decline in the desire for companionship ( Buhrmester and Furman 1987) and increase in conflict and experiencing a decrease in closeness with them (steinberg 1989), in addition to having fewer positive things to say to them. Parent adolescent interaction has a strong relationship to the wellbeing of the adolescents (Greenberg, Siegel, \& Leitch, 1983), and the lack of closeness with parents (Kandel \& Davies, 1982; Parker, Tupling, \& Brown, 1979) or a lower level of parental influence (Chrispin, 1998) correlates with a higher degree of behavioral problems in adolescents.

Parenting role differ by gender, and so do the relationship between mothers and daughters, fathers and daughters, mothers and sons, and fathers and sons. Studies also suggest that there are qualitative differences in parental involvement (Videon, 2005). Mothers are more typically

\footnotetext{
${ }^{1}$ Dean, Faculty of Home Science, Banasthali University, Rajasthan, India.

${ }^{2}$ Research Scholar, Human Development, Banasthali University, Rajasthan, India.

*Corresponding Author

(C) 2015 I I Bansal, S Sharma; licensee IJIP. This is an Open Access Research distributed under the terms of the Creative Commons Attribution License (http://creativecommons.org/licenses/by/2.0), which permits unrestricted use, distribution, and reproduction in any Medium, provided the original work is properly cited.
} 
primary caregivers and tend to spend more time taking care of their children and provide emotional care, whereas fathers give instrumental care and more likely to participate in leisure activities with their children (Paikoff \& Brooks-Gunn 1991) .

Studies generally focus on one parent or both parents without differentiating the gender of the parent but there are indications that parents tend to provide more companionship and general support to the same-sex child (Barber\& Thomas 1986). This fact motivated the researcher to take up this study. The purposes of this study are twofold- first to investigate parent-adolescent interaction and secondly to investigate whether or not gender and age acts as a moderator in the adolescent interaction with parents. Against this backdrop this study has been planned with the following objectives-

- To study the differences in parent-adolescents interaction and outcomes in context of class-wise and gender-wise

- To study the gender differences (girl Vs mother, girls Vs father and boy Vs mother, boy Vs father) in interaction and outcomes

\section{METHODOLOGY}

Data were collected from 18 (8 governments and 10 private) schools of New Delhi, selected randomly. Self constructed questionnaire was distributed to students studying in $7^{\text {th }}, 9^{\text {th }}$ and $11^{\text {th }}$ classes of these selected schools. Incomplete forms were screened out. Final sample comprised of 1719 adolescents (692 girls, 1027 boys) studying in $7^{\text {th }}(592), 9^{\text {th }}$ (564) and $11^{\text {th }}$ (563) classes to select the group of early, middle and late adolescents.

\section{Tool and methods}

In order to study the adolescent's perception of their interaction with parents and outcomes, a self constructed questionnaire was used. Various items to study the interaction and outcomes were categorized into 5 dimensions namely Quality of Interaction, Parental Support, Kind of Treatment, Punishment and Reward and Criticism/Complaints. Instructions were given separately for each section. Statements ranged from Yes/No to multiple choice types. Students were asked to mark their responses separately for mother and father in the given boxes. Means, Standard Deviation and ' $t$ ' test (to test the significance of difference between means) were calculated separately for different domains for age-wise and gender-wise differences. 


\section{RESULT AND DISCUSSION}

Table showing Mean SD and 't' values of various domains of parent-adolescent interaction and outcomes (Class-wise and Gender-wise)

\begin{tabular}{|c|c|c|c|c|c|c|c|}
\hline \multirow[t]{2}{*}{ Domains } & \multirow[t]{2}{*}{ variables } & \multirow[t]{2}{*}{$7^{\text {th }}$ class $(A)$} & \multirow[t]{2}{*}{$9^{\text {th }}$ class $(\mathrm{B})$} & \multirow[t]{2}{*}{$11^{\text {th }}$ class $(\mathrm{C})$} & $\mathbf{A B}$ & $\mathrm{AC}$ & BC \\
\hline & & & & & 't' value & 't' value & 't' value \\
\hline \multirow{3}{*}{$\begin{array}{l}\text { Quality of } \\
\text { interaction }\end{array}$} & Girl & $121.32 \pm 27.17$ & $129.48 \pm 19.70$ & $136.03 \pm 32.91$ & $3.83^{* *}$ & $5.15^{* *}$ & $2.55^{* *}$ \\
\hline & Boy & $128.24 \pm 38.85$ & $123.95 \pm 18.47$ & $135.62 \pm 26.29$ & \multirow[t]{2}{*}{$1.78 *$} & \multirow[t]{2}{*}{$2.98^{* *}$} & \multirow[t]{2}{*}{$6.65^{* *}$} \\
\hline & 't' & $2.44 * *$ & 3.41** & 0.16 & & & \\
\hline \multirow{3}{*}{$\begin{array}{c}\text { Parental } \\
\text { support }\end{array}$} & Girl & $79.68 \pm 9.10$ & $83 \pm 14.55$ & $92.68 \pm 15.68$ & $2.96^{* *}$ & $11.02^{* *}$ & $6.37^{* *}$ \\
\hline & Boy & $78.37 \pm 14.88$ & $83.90 \pm 15.42$ & $91.55 \pm 16.23$ & \multirow[t]{2}{*}{$4.77^{* *}$} & \multirow[t]{2}{*}{$10.08 * *$} & \multirow[t]{2}{*}{$5.54 * *$} \\
\hline & 't' & 1.24 & 0.71 & 1.35 & & & \\
\hline \multirow{3}{*}{$\begin{array}{l}\text { Kind of } \\
\text { treatment }\end{array}$} & Girl & $562.39 \pm 113.00$ & $501.06 \pm 85.30$ & $584.06 \pm 128.41$ & 0.36 & $1.88 *$ & $1.68 *$ \\
\hline & Boy & $576.79 \pm 84.36$ & $565.83 \pm 94.84$ & $615.01 \pm 104.73$ & $11.35 * *$ & $5.28 * *$ & $15.55 * *$ \\
\hline & 't' & 1.77* & $8.49 * *$ & 3.04** & & & \\
\hline \multirow{3}{*}{$\begin{array}{l}\text { Punishment } \\
\text { and reward }\end{array}$} & Girl & $285.89 \pm 37.25$ & $267.88 \pm 37.53$ & $361.09 \pm 87.06$ & $5.40 * *$ & $12.44 * *$ & $14.95^{* *}$ \\
\hline & Boy & $296.79 \pm 81.39$ & $269.98 \pm 46.05$ & $370.97 \pm 103.88$ & $5.13 * *$ & $10.44^{* *}$ & $16.07 * *$ \\
\hline & 't' & 2.22* & 0.57 & 1.11 & & & \\
\hline \multirow{3}{*}{$\begin{array}{l}\text { Criticism/ } \\
\text { complaints }\end{array}$} & Girl & $94.11 \pm 8.71$ & $84.44 \pm 14.41$ & $87.08 \pm 11.34$ & $9.19 * *$ & $7.39 * *$ & $2.04 *$ \\
\hline & Boy & $86.67 \pm 12.07$ & $79.38 \pm 13.78$ & $87.41 \pm 12.03$ & $7.16^{* *}$ & 0.80 & $8.20 * *$ \\
\hline & ' $t$ ' & $8.37 * *$ & $4.22 * *$ & 0.30 & & & \\
\hline
\end{tabular}


Table shows that as far as quality of interaction is concerned there is significant difference in quality of interaction among boys and girls. Quality of interaction improves significantly by age among girls and highest in $11^{\text {th }}$ class whereas it shows wave like trend for boys. There is significant decline in quality of interaction by $9^{\text {th }}$ as compared to $7^{\text {th }}$ class and then shows significant improvement by $11^{\text {th }}$ class. In $7^{\text {th }}$ class boys have better interaction than girls which improves in favor of girls by $9^{\text {th }}$ class and girls show better interaction with their parents. Quality of interaction improves further for both boys and girls by late adolescence $\left(11^{\text {th }}\right.$ class). Quality of interaction is more or less same for boys and girls studying in $11^{\text {th }}$ class.

Parental support also improves by age among both boys and girls and significantly better by late adolescents $\left(11^{\text {th }}\right.$ class). There are no gender differences for parental support as for all the three stages of development parental support is more or less same for boys and girls.

Kinds of treatment as well as Punishment and reward domains also show wave like development kind of treatment as well as punishment and reward decrease significantly from early to middle adolescence (as there is significant difference in two domains from $7^{\text {th }}$ to $9^{\text {th }}$ class). There is significant improvement in two dimensions by the late adolescence. Kind of treatment and reward are highest among late adolescents. There are also gender-wise differences. For all the three stages boys get better treatment as compared to girls. Punishment and reward were different for boys and girls in all stages of adolescence.

/complaints were significant in $7^{\text {th }}$ and $9^{\text {th }}$ class. It means both boys' and girls' .Criticism /complaints are different in pre, middle and late adolescent age (decrease in $9^{\text {th }}$ class than $7^{\text {th }}$ and further increase by $11^{\text {th }}$ class) .although showing wave like trend for different stages of there is significant gender difference in pre and middle adolescence. Girls reported more complaints and criticism than boys during early and middle adolescence but during late adolescence complaints and criticism are more or less same in both the sexes. 
Table showing Mean SD and ' $t$ ' test of various domains of parent-adolescent interaction and outcomes among father and mother Vs boys and girls

\begin{tabular}{|c|c|c|c|c|c|c|}
\hline \multirow[t]{2}{*}{ Domains } & \multicolumn{2}{|c|}{ Girls (G) } & \multicolumn{2}{|c|}{ Boys (B) } & \multirow[t]{2}{*}{ Variables } & \multirow{2}{*}{$\begin{array}{l}\text { 't' } \\
\text { value }\end{array}$} \\
\hline & $\begin{array}{c}\text { Father } \\
\text { (F) }\end{array}$ & $\begin{array}{l}\text { Mother } \\
\text { (M) }\end{array}$ & $\begin{array}{c}\text { Father } \\
\text { (F) }\end{array}$ & $\begin{array}{c}\text { Mother } \\
\text { (M) }\end{array}$ & & \\
\hline \multirow{4}{*}{$\begin{array}{l}\text { Quality of } \\
\text { interaction }\end{array}$} & \multirow{4}{*}{$\begin{array}{c}65.00 \\
\pm \\
15.04\end{array}$} & \multirow{4}{*}{$\begin{array}{c}64.69 \\
\pm \\
15.29\end{array}$} & \multirow{4}{*}{$\begin{array}{c}64.16 \\
\pm \\
13.66\end{array}$} & \multirow{4}{*}{$\begin{array}{c}63.89 \\
\pm \\
13.75\end{array}$} & F\&M for Girl & 0.46 \\
\hline & & & & & F\&M for Boy & 0.36 \\
\hline & & & & & $\begin{array}{l}\text { F for Boy \& } \\
\text { Girl }\end{array}$ & 1.18 \\
\hline & & & & & $\begin{array}{l}\text { M for Boy \& } \\
\text { Girl }\end{array}$ & 1.11 \\
\hline & & & & & & \\
\hline \multirow{4}{*}{ Parental support } & \multirow{4}{*}{$\begin{array}{c}42.22 \\
\pm \\
8.03\end{array}$} & \multirow{4}{*}{$\begin{array}{c}42.86 \\
\pm \\
11.48\end{array}$} & \multirow{4}{*}{$\begin{array}{c}42.05 \\
\pm \\
7.18\end{array}$} & \multirow{4}{*}{$\begin{array}{c}42.33 \\
\pm \\
7.77\end{array}$} & F\&M for Girl & 1.44 \\
\hline & & & & & F\&M for Boy & 0.69 \\
\hline & & & & & $\begin{array}{l}\text { F for Boy \& } \\
\text { Girl }\end{array}$ & 0.44 \\
\hline & & & & & $\begin{array}{l}\text { M for Boy \& } \\
\text { Girl }\end{array}$ & 1.04 \\
\hline & & & & & & \\
\hline \multirow{4}{*}{ Kind of treatment } & \multirow{4}{*}{$\begin{array}{c}283.45 \\
\pm \\
52.30\end{array}$} & \multirow{4}{*}{$\begin{array}{c}283.79 \\
\pm \\
52.88\end{array}$} & \multirow{4}{*}{$\begin{array}{c}283.88 \\
\pm \\
56.36\end{array}$} & \multirow{4}{*}{$\begin{array}{c}285.66 \\
\pm \\
57.78\end{array}$} & F\&M for Girl & 0.14 \\
\hline & & & & & F\&M for Boy & 0.57 \\
\hline & & & & & $\begin{array}{l}\text { F for Boy \& } \\
\text { Girl }\end{array}$ & 0.16 \\
\hline & & & & & $\begin{array}{l}\text { M for Boy \& } \\
\text { Girl }\end{array}$ & 0.69 \\
\hline \multirow{4}{*}{$\begin{array}{l}\text { Punishment and } \\
\text { reward }\end{array}$} & \multirow{4}{*}{$\begin{array}{c}142.15 \\
\pm \\
30.73\end{array}$} & \multirow{4}{*}{$\begin{array}{c}142.16 \\
\pm \\
28.31\end{array}$} & \multirow{4}{*}{$\begin{array}{c}149.55 \\
\pm \\
33.94\end{array}$} & \multirow{4}{*}{$\begin{array}{c}150.04 \\
\pm \\
33.39\end{array}$} & F\&M for Girl & 070 \\
\hline & & & & & F\&M for Boy & 0.27 \\
\hline & & & & & $\begin{array}{l}\text { F for Boy \& } \\
\text { Girl }\end{array}$ & $4.18 * *$ \\
\hline & & & & & $\begin{array}{l}\text { M for Boy \& } \\
\text { Girl }\end{array}$ & $3.46 * *$ \\
\hline & & & & & & \\
\hline \multirow{4}{*}{ Criticism/complaints } & \multirow{4}{*}{$\begin{array}{c}42.36 \\
\pm \\
6.46\end{array}$} & \multirow{4}{*}{$\begin{array}{c}42.40 \\
\pm \\
6.51\end{array}$} & \multirow{4}{*}{$\begin{array}{c}44.46 \\
\pm \\
6.30\end{array}$} & \multirow{4}{*}{$\begin{array}{c}44.35 \\
\pm \\
6.19\end{array}$} & F\&M for Girl & 0.11 \\
\hline & & & & & F\&M for Boy & 0.33 \\
\hline & & & & & $\begin{array}{l}\text { F for Boy \& } \\
\text { Girl }\end{array}$ & $6.66^{* *}$ \\
\hline & & & & & $\begin{array}{l}\text { M for Boy \& } \\
\text { Girl }\end{array}$ & $6.21 * *$ \\
\hline
\end{tabular}

As evident from the above table, for three dimensions Quality of interaction , Parental support and kind of treatment, all the ' $t$ ' values calculated for gender differences (girl Vs mother, girls 
Vs father and boy Vs mother, boy Vs father) are not significant subjected to acceptance null hypothesis for these dimensions. Quality of interaction, Parental support and kind of treatment is more or less same for boys and girls by father as well as mother.

As evident from the above table, for two domains (Punishment and Reward, Criticism/Complaints) there is significant difference in treatment of parents for boys and girls. Boys receive more punishment as well as reward by both of their parents (father and mother) as compared to girls and consequently boys have more complaints towards both of their parents as compared to girls. It may be concluded that girls have more interaction and get more support from parents in comparison to boys.

\section{CONCLUSIONS}

Quality of interaction of adolescents with their parents varies at different stages of adolescence. It is maximum at late adolescence and more or less of the same quality for both boys and girls. Interaction of boys and girls with parents at early and middle adolescence is quite different. During early years boys show better interaction with their parents which decreases considerably by middle adolescence years whereas quality of interaction of girls with their parents improves during middle adolescence, supersede boys and significantly better than boys.

Parental support shows upward trend from early to late adolescence for girls as well as for girls.

On other hand there is wave like trend for other three domains- 'Kind of treatment', 'Punishment and reward' and 'Criticism and complaints'. There is decrease in all the three domains from early to middle adolescence and then it shows significant increase in scores. When compared for boys and girls kind of treatment of parents for boy is better than girls in all the three stages of development, punishment and reward is better for boys during early adolescence but more or less same in middle and late adolescence. Parents have more Criticism/complaints from girls as to boys in early and middle adolescence.

When compared for gender of parents for boys and girls difference has been observed only in two domains 'Punishment and reward' and 'Criticism and complaints'. Father and mother have different treatment for boys and girls and more in favor of boys than girls. These results confirm findings that parental interaction and outcomes are affected by age and gender of adolescents.

\section{Following are some of the recommendations based on the findings of the study:}

- Parent should spend enough quality time with their children to enable them to develop appropriate behavior pattern.

- Parental supervision, monitoring, acceptance, warmth, demands, closeness, communication and involvement with adolescents should be examined time to time. In addition, it is important to understand the impacts of parents' interaction on adolescents.

- Parents should provide equal support and qualitative interaction or all the children irrespective of sex. They should not over criticize their wards and encourage healthy discussions. 


\section{REFERENCES}

Barber, B. K., \& Thomas, D. L. (1986). “Dimensions of fathers' and mothers' supportive behavior: The case for physical affection.”Journal of Marriage and the Family,48, pp.783-794

Chrispin, M. C. (1998) "Resilient adaptation of church affiliated young Haitian immigrants: A search for protective resources" (Doctoral dissertation, Teachers College, Columbia University, 1998). Dissertation Abstracts International.

Furman, W., \& Buhrmester, D. (1987) “Children's perceptions of the personal relationships in their social networks”. Developmental Psychology, 21, pp.1016-1024.

Greenberg, M., Siegel, J., \& Leitch, C. (1983) "The nature and importance of attachment relationships to parents and peers during adolescence." Journal of Youth and Adolescence, 12, pp.373-386.

Hoeve, M., Dubas, J. S., Eichelsheim, V. I., Laan, P. H., Smeenk, W., \& Gerris, J. R. M. (2009) "The relationship between parenting and delinquency: a meta-analysis." Journal of Abnormal Child Psychology, 37(6), pp.749-775.

Kandel, D. B., \& Davis, M. (1982) "Epidemiology of depressive mood in adolescents: An empirical study”. Archives of General Psychiatry, 39, pp.1205-1213.

Montemayor, R. (1983) "Parents and adolescents in conflict: All families some of the time and some families most of the time.” Journal of Early Adolescence, 3, pp.83-103.

Paikoff, R. L. \& Brooks-Gunn, J. (1991) "Do parent-child relationships change during puberty?” Psychological Bulletin, 110, pp.47-66.

Parker, G., Tupling, H., \& Brown, L. B. (1979) “A parental bonding instrument.” British Journal of Medical Psychology, 52, pp.1-10.

Steinberg, L. D. (1989) "Pubertal maturation and parent-adolescent distance: An evolutionary perspective.” In G. R. Adams, R. Montemayor \& T. P. Gullota (Eds), Biology of Adolescent Behavior and Development, pp. 71-97.

Steinberg, L., Elmen, J., \& Mounts, N. (1989) “Authoritative parenting, psychosocial maturity, and academic success among adolescents.” Child Development, 60, pp.1424-1436.

Videon, T. M. (2005) "Parent-child relations and children's psychological well-being: do dad matters?” Journal of Family Issues, 26(1), pp.55-78. 